The International Journal of Banking and Finance, Volume 9 (Number 1) 2012: pages 1-26

\title{
BOARD GENDER DIVERSITY, CORPORATE REPUTATION AND MARKET PERFORMANCE
}

\author{
Meredith B. Larkin, Richard A. Bernardi, and Susan M. Bosco \\ Roger Williams University, United States of America
}

\begin{abstract}
This study examines the association between corporate transparency, ethical orientation of Fortune 500 companies, the number of females represented on the board of directors as reported in the 2010 annual report data and respective stock performance. Our basis for this judgment was whether the firm was listed on either (both) Ethisphere Magazine's 2010 'World's Most Ethical Companies' or (and) Corporate Responsibility Magazine's 2010 '100 Best Corporate Citizens List'. Our results indicate that, as the number of women directors increased, the probability of a corporation appearing on these lists increases. Finally, while being on one of these lists did not increase corporate return data in a statistically significant sense, it did dramatically reduce the degree of negative returns.
\end{abstract}

Key Words: Ethical orientations, Corporate reputation, Market performance, Gender diversity JEL Classification: G39, M14

\section{Introduction}

Bernardi and several coauthors (2002 to 2010) examined various issues associated with female board members. Bernardi et al. $(2002,2005)$ found that corporations were more likely to include pictures of the board in their annual reports when the membership of their board included women (2002) and/or minorities (2005). Bernardi et al. also found that corporations with higher percentages of women on their boards were more likely to be on '100 best companies to work for' (2006) and 'most ethical companies' (2009) lists; have a higher percentage of female executives (2004); and, engage in activities demonstrating corporate social responsibility (2010). However, the 'so what' question remains concerning the increase in female representation on 
corporate boards and corporate reputation, which equates to the public's overall perception of a corporation (Fombrun and Shanley, 1990).

While the number of women on corporate boards has increased by approximately 28 women per year between 1977 and 2001 (Bernardi et al., 2006), it is still relatively low at 832 female directors of 5,613 directors on Fortune 500 boards (Bernardi et al, 2009). Stakeholders with legitimate interests (Donaldson and Preston, 1995) have lost billions of dollars due to recent corporate scandals. Following the corporate scandals in 2002 and new regulatory actions, it is surprising to find that the percent of women on boards has not increased substantially. While women directors made up 11.9 percent of Fortune 500 boards in 2002, they now make up 14.4 percent (Bernardi et al., 2009). The 2.5 percent increase represents an additional 156 female directors of approximately 5,600 directors (Bernardi et al, 2002 and 2009). ${ }^{1}$ Gender diversity on corporate boards associates with financial performance (Carter et al., 2008), reduction in the inherent risk (Ittonen et al., 2007), positive market reactions (Defond et al., 2005), and positive cumulative abnormal returns (Huang et al., 2011).

The need for organizations to become better corporate citizens and improve their levels of corporate social responsibility has become increasingly evident. Our sample includes the 2010 Fortune 500 corporations of which 92 (408) corporations appear (do not appear) on Corporate Responsibility Magazine’s (hereafter CRM) '100 Best Corporate Citizens List'. Our sample also includes the 46 (454) corporations that appear (do not appear) on Ethisphere Magazine's (hereafter EM) 2010 'World's Most Ethical Companies' list.

Our research indicates that stakeholder advocate organizations (i.e., $C R M$ and $E M$ ) tend to recognize corporations that have higher proportions of women on their boards. The interaction of this recognition and multiple female board members for the corporations in this sample associated with higher overall returns and lower negative returns for stockholders' wealth as measured by the market prices of the corporations' common stock.

\footnotetext{
${ }^{1}$ Of the 5,514 directors on Fortune 500 boards included in this research, there are 863 female directors (15.1 percent).
} 


\section{Literature Review and Hypotheses}

\subsection{Board Duties}

An organization's board of directors is responsible for ensuring that a corporation is meeting the objectives of stakeholders as well as developing business strategies to prosper in the future (Arfken et al., 2004; Peterson and Philpot, 2007). When the corporation fails to meet these objectives, many question the ability of the board members. Campbell and Minguez-Vera (2008) indicate that the effectiveness of a board depends heavily on each board member's qualifications and experience. Historically, older white males dominated; consequently, as corporate scandals continue, stakeholders push for changes in the corporate structure (McDaniel et al, 2001; Farrell and Hersch, 2005). Recent scandals indicate that corporations are not meeting these objectives; this suggests that the current homogenous boardroom is unable to perform its duties (Campbell and Minguez-Vera, 2008; Burke, 1997; Arfken et al., 2004). Companies now face an investing public that demands scrutiny of all corporate decisions and expects board members to be accountable for their actions (Arfken et al. 2004).

Consumers and shareholders question the ability of a homogenous boardroom (Arfken $e t$ $a l ., 2004)$; consequently, there has been a call for a higher representation of women on corporate boards (Burke, 1997). Many feel that the presence of women on corporate boards adds a sense of moral obligation to a corporation's decision-making process (Arfken et al., 2004) which can in turn improve boardroom transparency and limit the likelihood of corporate scandal. The underrepresentation of women on boards became public in 1977 (Special Report, 1977); research continues to depict this trend (Burgess and Tharenou, 2002). Boards should not overlook their female board members and should take initiatives to ensure the consideration of female board members' viewpoints. Burke (1997) indicates that the benefits to both internal and external stakeholders of considering female board members' viewpoints include a more comprehensive decision making-process that is both creative and innovative. Women are able to bring a new perspective to the homogenous boardroom including raising issues that affect a wider range of stakeholders and using interpersonal skills to promote discussion (Kramer et al., 2007). 


\subsection{Board Diversity}

Research has shown that lack of diversity within a boardroom results in a manila mindset to solving corporate problems (Burgess and Tharenou, 2002) that can lead to group think issues as well as lack of achievement within the company. Over the past decade, homogenous boards have been a contributing factor to spectacular failures and overall poor governance (Brown et al., 2002). A more diverse board results in an increased representation of moral and ethical viewpoints in the discussions prior to making decisions (Arfken et al., 2004). Diversity limits the possibility of a myopic decision-making process that can result in "unhealthy and possibly unethical decisions" (Arfken et al., 2004 p. 185) when the board has similar demographics. Many studies have cited that diversity not only limits the likelihood of myopic decision-making process but also increases the likelihood of positive occurrences such as fresh ideas, better problem solving, improved strategic planning, and additional accountability (Arfken et al., 2004). Diversity in the boardroom allows members to make better decisions as a more complete picture of the issues at hand are typically discussed (Adams and Flynn, 2005). Adams and Ferreira's (2009) research indicates that diverse boards are more likely to hold CEOs responsible for poor stock price performance and that board compensation is typically equity-based, implying that the board is more aligned with shareholder interests. These findings further the idea that having women on boards can add value to a company.

Overall, gender-diverse boards have increased levels of boardroom involvement and corporate oversight (Adams and Ferreira, 2009); boards with a greater female presence have higher levels of meeting attendance. The primary way in which boards operate and conduct business is through meetings and thus, attendance is a crucial factor of a successful board (Adams and Ferreira, 2009). These authors note that women were less likely to have attendance problems and that having females on boards results in better attendance by male directors. Clearly, the female influence in this area is quite important; increasing attendance should result in better boardroom discussion and higher levels of effectiveness.

An increased membership of female directors positively associated enhanced corporate reputation (Bear et al., 2010). Bernardi et al. also found that corporations with higher percentages of women on their boards were more likely to be named as one of the '100 best 
companies to work for' (2006), one of the 'most ethical companies' (2009), and a higher number of female executive-level managers (2004).

\subsection{Ethical Orientation}

The individuals an organization attracts, hires, and retains influence the organization's ethical climate (Schneider, 1987). Harrison (1992) indicates that factors essential to economic success include a sense of community (i.e. a trusting and caring environment - Reynolds, 2003) and a robust ethical system. Employees are more likely to support a corporation's values when the corporation demonstrates a commitment to the welfare of its community (Barnett and Schubert, 2002). Young people are attracted to a company's social record (Goodpaster, 1991);

for example, Bernardi and Guptill (2008) found that women from eight countries who were approaching graduation were more concerned about a corporation's reputation within its community than were their male counterparts. Consequently, as Arnold et al. (1997) suggest, the foundation of an ethical organization culminates in an environment that nurtures ethical behavior.

Bernardi and Arnold (1997) and Akaah (1989) indicate a difference between males' and females' moral reasoning and development implying that the way men and women handle ethical decision-making differs. Williams (2003) makes clear the correlation between increased levels of female directors and a company's involvement in corporate social responsibility activities. The more concerned the firm is with issues of corporate responsibility, the less likely the firm will take actions that are considered unethical or do not promote the overall wellbeing of the firm and the surrounding environment. In a corporate landscape where corruption is rampant, it is essential that corporations work to ensure their culture is ethical and women are able to enhance this important aspect (McDaniel et al., 2001). Bernardi et al. found that corporations with higher percentages of women on their boards were more likely to be on EM's 'most ethical companies' list (2009) and engage in activities demonstrating corporate social responsibility (2010).

\subsection{Transparency}

While ethical orientation is concerned with the internal decisions that an organization makes, transparency focuses on whether stakeholders have access to this information. An organization's reputation rests on its stakeholders trust (Larkin, 2003), which directly relates to 
the information that is available about the organization (i.e., the transparency of the company). Public disclosure of information has increased in an effort to increase trust in organizations because trust at all levels is essential to a corporation's legitimacy (The Economist, 2000). Following instances such as Enron, the Big-Four firms have all indicated a commitment to ethics and transparent reporting (Lehman, 1992). Deloitte and Touche initiated a challenge to restore the profession's public trust (Parrett, 2004) and both KPMG (2003) and PricewaterhouseCoopers (2003) call for increased transparency and integrity in corporate reporting.

Organizations that are not forthcoming with information tend to be hiding essential facts from stakeholders; this process leads to the possibility of corporate scandal. The lack of transparency and audit failure contributed to the Enron debacle - one of the most discussed financial scandals. Reinstein and McMillan (2004) show that Enron's collapse was not a perfect storm (i.e., a happenstance of rare events that had devastating effects). Rather, the audit team from Andersen ignored or missed red flags that would have indicated problems with Enron's financial heath (Reinstein and McMillan, 2004). In this case, understanding the organization's operations would have lead stakeholders to question Enron's profits and financial statements.

\subsection{Women and Economic Performance}

Businesses operate with the objective to earn a profit and in turn increase shareholder value. Corporate managers, and those who are interested in positive governance, believe that there is a correlation between board diversity and shareholder value (Carter et al., 2003). Furthermore, investors are willing to pay more for firms with effective corporate governance (Smalhout, 2003). Jackson (2004) found that most individuals consider reputation in their investment decisions; research also suggests that stock performance associates with corporate reputation (Miles and Covin, 2000; Vergin and Qoronfleh, 1998; Sparks, 1998; Sims, 1994).

Many corporations recognize that increasing shareholder value should occur in an ethical manner, but the implementation of this process can be difficult. Corporations are under increasing pressure to act in a socially responsible manner while still attaining high profit levels. Corporate social responsibility is the implementation of policies that recognize the relationship among business ethics, community investment, governance and many other aspects of business (Tsoutsoura, 2004; Bernardi et al., 2006). 
Prior research demonstrated the benefits that having women on boards can bring to an organization, but many question the ability of organizations to be socially responsible while still meeting shareholder expectations. Some feel that social responsibility results in increased cost pressures on organizations, which can affect the bottom line. However, corporations that engage in socially responsible practices can more easily obtain capital as their reputation of being less risky (Tsoursoura, 2004). Together, these aspects help improve the public's view of the firm thus increasing profitability. Tsoursoura also found that financial performance and corporate social responsibility were positively associated. Most importantly, Tsoursoura found that the industries with the lowest ratings for social responsibility include mining and construction, the same sectors with the lowest number of women on boards (GovernanceMetrics International, 2010). These findings show that having women on boards does in fact positively affect the social responsibility behaviors of an organization. Bear et al. (2010) found that the number of female directors positively associated with measures of corporate reputation. Bernardi et al. (2006) also

found that an increased proportion of female representation on boards associated with the corporation's inclusion on the '100 Best Companies to Work For' list.

Additionally, corporations that value diversity have proven to be more competitive in the overall business setting (McDaniel et al, 2001). Farrell and Hersch (2005) conducted research on the effect that women board members have on a corporation's common stock performance. They found that, while adding women to the board positively associated with return on assets, the market failed to react to adding women to a board. This information supports the idea that having women on boards has a direct impact on the bottom-line profits of an organization, but at this point fails to influence investor opinion.

\subsection{Hypothesis Development}

While overconfidence in decision-making occurs in both men and women, men are typically more overconfident than women are especially in areas considered masculine (i.e., financial decisions) (Lundeberg et al., 1994). Barber and Odean (2000) found that men tended to turn over their portfolios more often and have lower returns than women; they suggest that overconfidence leads to high levels of counterproductive trading. Huang and Kisgen (2008) found that female CFO's tended to be more risk adverse, used debt less frequently to finance corporate capital demands, made fewer acquisitions, and outperformed corporations with male 
CFOs. Consequently, women can also bring different viewpoints/attitudes to an organization through board membership.

Carter et al. (2003) indicate that gender diversity enhances understanding of the intricacies of a corporation's market. Women are able to bring their insights to the boardroom and match the diversity of the organization's consumer base. In general, boards that closely match the makeup of the general population provide improved corporate social performance (Bernardi et $a l ., 2006)$. Diversity also allows an organization to view problems in a different manner and reevaluate the way in which they do business. Prior research shows that improved performance associates with boards that are diverse with respect to gender (Brady, 2007; Cohen and Kornfeld, 2006).

Adding female board members has proven to increase an organization's sense of responsibility. Carter et al. (2008) noted that the effect of gender diversity on a board's audit function associated with financial performance. Ittonen et al. (2007) found that, when female board members are on the board's audit committee, there was a reduction in the inherent risk of financial misstatements. These authors also noted that gender diversity associates with lower audit fees. Audit committees that include women tend to be more conservative; Thiruvadi and Huang (2011) report that, when female directors were members of audit committees, corporations tended to report increased negative accruals, which decrease income. When new audit committee members had accounting expertise, the market reacted positively (Defond et al., 2005). Huang et al. (2011) found that, when compared to the addition of male board members, the addition of female board members to the audit committee resulted in positive cumulative abnormal returns. ${ }^{2}$ Gender diversity can be beneficial in situations involving complex tasks, which require creative decision-making (Kravitz, 2003). Consequently, expanding a board's viewpoint can facilitate increased discussion, better problem solving tactics, and a better understanding of the marketplace as a whole.

Gul et al. (2011) found that board-gender diversity encouraged corporations to increase their disclosure of corporate data. Bernardi et al. found that corporations with higher percentages

\footnotetext{
${ }^{2}$ While Nguyen and Faff (2006) found that gender diversity associated with higher firm values, Wang and Clift (2009) found that gender and racial diversity did not influence firm performance - both studies used listed Australian corporations.
} 
of women on their boards were more likely to be on '100 best companies to work for' (2006) and 'most ethical companies' (2009) lists. However, this research fails to associate female directors and listings with financial performance, which leads to our research hypotheses (stated in their alternate form):

$\mathbf{H}_{1}$ : The corporations on CRM's (2010) list will have a higher (lower) proportion of multiple female directors (zero or only one director) than for corporations not on this list.

$\mathbf{H}_{2}$ : The corporations on EM's (2010) list will have a higher (lower) proportion of multiple female directors (zero or only one director) than for corporations not on this list.

$\mathbf{H}_{3}$ : Membership on CRM's (2010) list will associate with higher (lower) increases (decreases) in common stock prices in 2010.

$\mathbf{H}_{4}$ : Membership on EM's (2010) list will associate with higher (lower) increases (decreases) in common stock prices in 2010 .

\section{Data and Methodology}

\subsection{Sample}

The current sample includes the 2010 Fortune 500 corporations of which 92 (408) corporations appear (do not appear) on CRM's list (Table 1). The sample also includes the 46 (454) corporations that appear (do not appear) on EM's 2010 list (Table 2). Appendix A provides the methodology for CRM's list. Appendix B provides the methodology for EM's list. We determined the size and gender composition of the corporate boards of directors by referring to the companies' actual 2010 annual reports or from data included in the Mergent Online database.

\subsection{Selection Processes and Corporate Return Data}

CRM's list (Appendix A) took into consideration both the transparency and the level of social responsibility of an organization. It is important to note that our basis for considering an organization as transparent lies with the fact that the magazine penalized corporations for not disclosing information relating to social responsibility. EM's list (Appendix B) acknowledges corporations for being ethical and following compliance measures through positive leadership.

We tested the research question relating to the organization's financial return using a rate of return for the period between January 1, 2010 and December 31, 2010. We used historic stock 
prices to determine the price per share of each organization at the earliest available stock price in 2010 in relation to the latest available stock price in 2010 at the close of the trading day. In order to determine the percentage change of the stock price for the given year, we subtracted the beginning (January 1) stock price from the ending (December 31) stock price, which we divided by the beginning stock price.

Table 1: Most Transparent Companies

\begin{tabular}{|c|c|c|}
\hline $3 \mathrm{M}$ & Ford Motor & Northeast Utilities \\
\hline Abbott Laboratories & FPL Group & Occidental Petroleum \\
\hline Advanced Micro Devices & Freeport-McMoRan Copper \& Gold & Oracle \\
\hline Air Products \& Chemical & Gap & Owens Corning \\
\hline Alcoa & General Mills & Pepsi Bottling \\
\hline Allergan & H.J. Heinz & PepsiCo \\
\hline Applied Materials & Hess & PG\&E Corp. \\
\hline Avon Products & Hewlett-Packard & Procter \& Gamble \\
\hline Ball & Hormel Foods & Quest Diagnostics \\
\hline Baxter International & Intel & Raytheon \\
\hline Boeing & International Business Machines & Sara Lee \\
\hline Bristol-Myers Squibb & International Paper & Sempra Energy \\
\hline Campbell Soup & ITT & Sherwin-Williams \\
\hline Chevron & J.C. Penney & Southern \\
\hline Cisco Systems & J.P. Morgan Chase \& Co. & Staples \\
\hline Citigroup & Johnson \& Johnson & Starbucks \\
\hline Coca-Cola & Johnson Controls & State Street Corp. \\
\hline Coca-Cola Enterprises & Kellogg & Stryker \\
\hline Colgate-Palmolive & Kimberly-Clark & Texas Instruments \\
\hline ConAgra Foods & Lubrizol & TJX \\
\hline Consolidated Edison & Mattel & Union Pacific \\
\hline Cummins & McDonald's & United Parcel Service \\
\hline CVS Caremark & McGraw-Hill & Verizon \\
\hline Deere & McKesson & Wal-Mart Stores \\
\hline Dell & Medtronic & Walt Disney \\
\hline Dominion Resources & Merck & Weyerhaeuser \\
\hline Duke Energy & Microsoft & Wisconsin Energy \\
\hline Eaton & Monsanto & Xcel Energy \\
\hline EMC & Mosaic & Xerox \\
\hline Exelon & Newmont Mining & Yum Brands \\
\hline Exxon Mobil & Nike & \\
\hline
\end{tabular}




\subsection{Board Gender Data}

While our initial analysis included all Fortune 500 corporations, 51 of these corporations are not publicly listed; of the 51 corporations that were not publicly traded, three of them were on CRM's list. For the 89 publicly traded corporations that appear on CRM's list, there were 195 female directors and 1057 total directors (18.4 percent). The 89 corporations on CRM's list make up 19.8 percent of the 449 publicly traded companies in the Fortune 500. Our data indicate that of the 89 corporations on CRM's list: 1.1 percent had no female directors; 21.3 percent had one female director; and, 77.5 percent had multiple female directors. We compared these percentages to those for the remaining 406 corporations that have 586 female directors and 3,904 total directors (15.0 percent). The data for these corporations indicate that: 14.4 percent had no female directors; 32.2 percent had one female director; and, 55.3 percent had multiple female directors.

\section{Table 2: Most Ethical Companies}

\begin{tabular}{lll} 
Aflac & Flour & Pitney Bowes \\
American Express & Ford Motor & Principal Financial \\
Aramark & FPL Group & Rockwell Automation \\
Ashland & Gap & Rockwell Collins \\
Becton Dickinson & General Electric & Sempra Energy \\
Best Buy & General Mills & Starbucks \\
Campbell Soup & Google & Symantec \\
Caterpillar & Harris & Target \\
CH2M Hill & Hartford Financial Services & Texas Instruments \\
Cisco Systems & Hewlett-Packard & Time Warner \\
Cummins & International Paper & United Parcel Service \\
Deere & Johnson Controls & Waste Management \\
Duke Energy & Mattel & Weyerhaeuser \\
Eaton & Nike & Whole Foods Market \\
Ecolab & PepsiCo & Wisconsin Energy \\
& & Xerox \\
\hline
\end{tabular}

Three of the 46 corporations that appear on EM's list are not publicly traded. For the 43 publicly traded corporations that appear on EM's list, there are 93 female directors and 491 total directors (18.9 percent). Our data indicate that of those: 2.3 percent had no female directors; 23.3 percent had one female director; and, 74.4 percent had multiple female directors. We compared 
these percentages to those for the remaining 406 corporations that have 688 female directors and 4,470 total directors (15.4 percent). The data for these corporations indicate that: 12.8 percent had no female directors; 30.8 percent had one female director; and, 56.4 percent had multiple female directors.

\section{Analyses and Findings}

\subsection{Overview}

For this part of the analysis, we used the data from 449 of the Fortune 500 companies that had publicly listed performance data - the other 51 companies were not publicly listed. In our analysis, we group corporations by whether or not they appear on a specific list and by the number of female board members: no female board members, one female board member, and multiple female board members. In our examination of the data, we use contingency analysis, as we believe it visually demonstrates our findings with respect to listing by either $C R M$ or $E M$, board gender diversity and common stock performance.

\subsection{Corporate Reputation and Female Board Members (H1 and H2)}

This part of the analysis tests for an association between listing by either $C R M$ or $E M$ and gender. For the 89 corporations included on $C R M$ 's list, there was one corporation (1.1 percent) with no female directors, 19 corporations (21.4 percent) with one female director and 69 corporations (77.5 percent) with multiple female directors. For the 360 corporations that were not included on CRM's list, there were 52 corporations (14.5 percent) with no female directors, 126 corporations (32.2 percent) with one female director and 192 corporations (53.3 percent) with multiple female directors. While the corporations not listed by CRM had a higher proportion

of corporations with no female directors or only one female director (14.5 and 32.2 percent respectively) than the corporations listed by $C R M$ (1.1 and 21.4 percent respectively), the reverse is true for corporations with multiple female directors (53.3 versus 77.5 percent respectively). Panel A of Table 3 shows the actual and expected number of female directors for each of group 
or corporations. ${ }^{3}$ Our analysis indicates that all treatments are not proportionally represented $\left(\chi^{2}\right.$ statistic $\left.=20.72, \mathrm{p}<0.000\right)$. The most significant contributors to this difference were the corporations listed by $C R M$. Corporations on CRM's list had higher proportion of corporations with multiple female directors, which supports our first research hypothesis.

For the 43 corporations included on EM's list, there was one corporation (2.3 percent) with no female directors, 10 corporations (23.3 percent) with one female director and 32 corporations (74.4 percent) with multiple female directors. For the 406 corporations that were not included on EM's list, there were 52 corporations (12.8 percent) with no female directors, 125 corporations (30.8 percent) with one female director and 229 corporations (56.4 percent) with multiple female directors. While the corporations not listed by EM had a higher proportion of corporations with no female directors or only one female director (12.8 and 30.8 percent respectively) than the corporations listed by EM (2.3 and 23.3 percent respectively), the reverse is true for corporations with multiple female directors (56.4 versus 74.4 percent respectively).

Panel B of Table 3 shows the actual and expected number of female directors for each of group or corporations. Our analysis indicates that all treatments are not proportionally represented

$\left(\chi^{2}\right.$ statistic $\left.=6.52, \mathrm{p}=0.045\right)$. The most significant contributors to this difference were the corporations listed by EM. Corporations on EM's list had higher proportion of corporations with multiple female directors, which supports our second research hypothesis.

\subsection{Corporate Reputation and Performance (H3 and H4)}

This part of the analysis tests for an association among listing by either CRM or EM and corporate performance. On an overall basis, the data indicate that the 89 (360) corporations (not) included on CRM's list had an increase of 11.9 (6.7) percent - average return of 7.7 percent. The 43 (406) corporations (not) included on EM's list had an increase of 16.2 (6.8) percent

\footnotetext{
${ }^{3}$ In our contingency analysis, we computed the expected number of companies for each group by multiplying the total number of corporations in each column (i.e., the number of female directors on the board) by proportion of the sample (i.e., either the number of transparent or remaining companies divided by the total sample). For example, for the 16 transparent companies that have one female director, we would expect to have 26.8 companies ([19+116] X [89/449]) rather than our actual count of 19 companies. Similarly, for the remaining companies with one female director, we would expect to have 108.2 companies ([19+116] X [360/449]) rather than our actual count of 116 companies.
} 
TABLE 3: LISTING BY CRM OR EM AND BOARD GENDER COMPOSITION

\begin{tabular}{|c|c|c|c|c|c|}
\hline \multicolumn{6}{|l|}{ Panel A: $C R M^{\prime} \mathrm{S}$ listing } \\
\hline \multirow{4}{*}{ Transparent corporations } & & None & One & Multiple & Total \\
\hline & Actual & $\overline{1}$ & $\overline{19}$ & 69 & $\overline{89}$ \\
\hline & Expected & 10.5 & 26.8 & 51.7 & 89 \\
\hline & $\chi^{2}$ stat & 8.60 & 2.25 & 5.76 & 16.61 \\
\hline \multirow[t]{3}{*}{ Remaining corporations } & Actual & 52 & 116 & 192 & 360 \\
\hline & Expected & 42.5 & 108.2 & 209.3 & 360 \\
\hline & $\chi^{2}$ stat & 2.13 & 0.56 & 1.43 & 4.11 \\
\hline \multicolumn{6}{|l|}{ Panel B: $E M^{\prime} S$ listing } \\
\hline & \multicolumn{5}{|c|}{$\underline{\text { Number of Female Directors }}$} \\
\hline \multirow{4}{*}{ Ethical corporations } & & None & One & Multiple & Total \\
\hline & Actual & 1 & $\overline{10}$ & 32 & $\overline{43}$ \\
\hline & Expected & 5.1 & 12.9 & 25.0 & 43 \\
\hline & $\chi^{2}$ stat & 3.27 & 0.66 & 1.96 & 5.90 \\
\hline \multirow[t]{3}{*}{ Remaining corporations } & Actual & 52 & 125 & 229 & 406 \\
\hline & Expected & 47.9 & 122.1 & 236.0 & 406 \\
\hline & $\chi^{2}$ stat & 0.35 & 0.07 & 0.21 & 0.63 \\
\hline
\end{tabular}


- average return of 7.7 percent. Consequently, on an overall basis, our first two hypotheses about being on a listed by either $C R M$ or $E M$ and higher common stock prices were supported by the data. Panel A of Table 4 provides the average returns for the six groups of companies. Our analysis indicates that all treatments did not have a 7.7 percent increase in common stock value $\left(\chi^{2}\right.$ statistic $\left.=8.06, p=0.02\right) .{ }^{4}$ The most significant contributors to this difference were the corporations listed by $C R M$ with one female director and multiple female directors. It is the higher percent of increase for corporations listed by CRM that are driving the difference in treatments. We further divided the data in Panel A by whether their common stock price increased (Panel B) or decreased (Panel C) for additional analysis.

For the corporations in Panel B, the average increase in their stock price was 19.9 percent. The data in Panel B indicate no difference in treatments $\left(\chi^{2}\right.$ statistic $=1.23$, not significant $)$ for the corporations whose common stock prices increased. For the corporations in Panel C, the average decrease in their stock price was 38.0 percent. The data in Panel C indicate that not all treatments had a 38.0 percent decrease in common stock value $\left(\chi^{2}\right.$ statistic $=54.91$, $\mathrm{p}<0.000$ ). Again, our data indicates that the most significant contributors to this difference were the corporations listed by $C R M$ with one female director and multiple female directors. The common stock prices for the 19 corporations listed by $C R M$ (average $=-9.1$ percent) did not decrease as much as the 76 corporations that were not listed (average $=-45.2$ percent). Consequently, the data support our third hypothesis.

Panel A of Table 5 provides the average returns for the six groups of companies. Our analysis indicates that not all treatments had a 7.7 percent increase in common stock value $\left(\chi^{2}\right.$ statistic $\left.=20.62, p<0.000\right)$. The most significant contributors to this difference were the corporations listed by $E M$ with one female director and multiple female directors. It is the higher percent of increase for corporations listed by $E M$ that are driving the difference in treatments. We further divided the data in Panel A by whether their common stock price increased (Panel B) or decreased (Panel C) for additional analysis.

\footnotetext{
${ }^{4}$ We did not include the data for the first group (i.e., being listed by either $C R M$ or $E M$ and no female directors) as there was only one firm in this group (i.e., return of 31.5 percent was not an average).
} 


\section{TABLE 4: AVERAGE PERCENT CHANGE IN SHARE PRICE AND CRM'S LISTINGS}

\begin{tabular}{|c|c|c|c|c|c|}
\hline \multicolumn{5}{|c|}{ Panel A: Average Percent Change for all Corporations (average $=7.7$ percent) } & \\
\hline \multirow{4}{*}{ Transparent corporations } & & None & One & Multiple & $\underline{\text { Total }}$ \\
\hline & $(\%)$ & $\overline{31.3}$ & $\overline{13.9}$ & 10.8 & $\overline{11.9}$ \\
\hline & (n) & $(1)$ & $(19)$ & $(69)$ & $(89)$ \\
\hline & $\chi^{2}$ stat & NA & 5.04 & 1.27 & 6.31 \\
\hline \multirow{3}{*}{ Remaining corporations } & $(\%)$ & 10.5 & 5.8 & 6.3 & 6.7 \\
\hline & (n) & (52) & (116) & (192) & $(360)$ \\
\hline & $\chi^{2}$ stat & 1.04 & 0.46 & 0.25 & 1.71 \\
\hline \multicolumn{6}{|c|}{ Panel B: Average Percent Change for Corporations with Positive Returns (average = 19.9 percent) } \\
\hline \multicolumn{6}{|c|}{ Number of Female Directors } \\
\hline \multirow{4}{*}{ Transparent corporations } & & $\underline{\text { None }}$ & $\underline{\text { One }}$ & Multiple & $\underline{\text { Total }}$ \\
\hline & $(\%)$ & $\overline{31.3}$ & $\overline{17.8}$ & 16.9 & 17.3 \\
\hline & (n) & $(1)$ & $(16)$ & $(53)$ & (70) \\
\hline & $\chi^{2}$ stat & NA & 0.22 & 0.46 & 0.68 \\
\hline \multirow[t]{3}{*}{ Remaining corporations } & $(\%)$ & 23.2 & 20.3 & 20.0 & 20.6 \\
\hline & (n) & (43) & $(92)$ & $(149)$ & $(284)$ \\
\hline & $\chi^{2}$ stat & 0.54 & 0.01 & 0.00 & 0.55 \\
\hline \multicolumn{6}{|c|}{ Panel C: Average Percent Change for Corporations with Negative Returns (average $=-38.0$ percent) } \\
\hline \multirow{4}{*}{ Transparent corporations } & & None & One & Multiple & $\underline{\text { Total }}$ \\
\hline & $(\%)$ & NA & -6.9 & -9.5 & -9.1 \\
\hline & (n) & $(0)$ & (3) & (16) & (19) \\
\hline & $\chi^{2}$ stat & NA & 25.47 & 21.39 & 46.86 \\
\hline \multirow[t]{3}{*}{ Remaining corporations } & $(\%)$ & -50.4 & -49.8 & -41.5 & -45.2 \\
\hline & (n) & (9) & (24) & (43) & (76) \\
\hline & $\chi^{2}$ stat & 4.05 & 3.67 & 0.33 & 8.05 \\
\hline
\end{tabular}


For the corporations in Panel B, the average increase in their stock price was 19.9 percent. The data in Panel B indicate no difference in treatments $\left(\chi^{2}\right.$ statistic $=0.90$, not significant $)$ for the corporations whose common stock prices increased. For the corporations in Panel C, the average decrease in their stock price was 38.0 percent. The data in Panel $\mathrm{C}$ indicate that not all treatments had a 38.0 percent decrease in common stock value $\left(\chi^{2}\right.$ statistic $=50.93$, $\mathrm{p}<0.000$ ). Again, the most significant contributors to this difference were the corporations listed by $C R M$ with one female director and multiple female directors. The common stock prices for the six corporations listed by $E M$ (average $=-10.1$ percent) did not decrease as much as the 89 corporations that were not listed (average $=-39.8$ percent). Consequently, the data support our third hypothesis.

This section of our analysis found that corporations on both CRM and EM's lists had higher average increases in their common stock prices (Panel A of Tables 4 and 5). When we separated the companies according to whether they had increasing or decreasing stock prices, there were no significant differences in the two groups with increasing stock prices (Panel B of Tables 4 and 5).

However, we found that the decrease in common stock prices for corporations on both $C R M$ and EM's lists was not as large as the decrease for corporations not on these lists (Panel C of ables 4 and 5). Consequently, our data indicate an association between a corporation's reputation (i.e., being on either $C R M$ or $E M$ 's list) and common stock performance.

\section{Conclusions}

The major contribution of this paper is that board gender diversity can provide an incremental benefit for corporations that already have a good reputation in ethical behavior, social responsibility and transparency. Our data indicate that companies on CRM or EM's lists have superior returns and that companies on $C R M$ or $E M$ 's lists are more likely to have multiple female directors on their boards. Consequently, our data suggest an interactive effect between corporate reputation and the number of female directors. 


\section{TABLE 5: AVERAGE PERCENT CHANGE IN SHARE PRICE AND EM'S LISTINGS}

\begin{tabular}{|c|c|c|c|c|c|}
\hline \multicolumn{6}{|c|}{ Panel A: Average Percent Change for all Corporations (average $=7.7$ percent) } \\
\hline Ethical corporations & $\begin{array}{c}(\%) \\
(\mathrm{n}) \\
\chi 2 \text { stat }\end{array}$ & $\begin{array}{c}\text { None } \\
10.7 \\
(1) \\
\text { NA }\end{array}$ & $\begin{array}{l}\frac{\text { One }}{15.9} \\
(10) \\
8.80\end{array}$ & 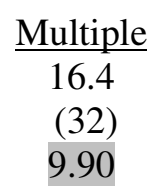 & $\begin{array}{r}\frac{\text { Total }}{16.2} \\
(43) \\
18.70\end{array}$ \\
\hline Remaining corporations & $\begin{array}{c}(\%) \\
(\mathrm{n}) \\
\chi 2 \text { stat }\end{array}$ & $\begin{array}{l}10.9 \\
(52) \\
1.35\end{array}$ & $\begin{array}{c}6.2 \\
(125) \\
0.29\end{array}$ & $\begin{array}{c}6.2 \\
(229) \\
0.29\end{array}$ & $\begin{array}{c}6.8 \\
(406) \\
1.93\end{array}$ \\
\hline \multicolumn{6}{|c|}{$\begin{array}{r}\text { Panel B: Average Percent Change for Corporations with Positive Returns (average }=19.9 \text { percent) } \\
\text { Number of Female Direc }\end{array}$} \\
\hline Ethical corporations & $\begin{array}{c}(\%) \\
(\mathrm{n}) \\
\chi 2 \text { stat }\end{array}$ & $\begin{array}{c}\text { None } \\
10.7 \\
(1) \\
\text { NA }\end{array}$ & $\begin{array}{r}\frac{\text { One }}{21.5} \\
(8) \\
0.13\end{array}$ & $\begin{array}{c}\text { Multiple } \\
20.5 \\
(28) \\
0.02\end{array}$ & $\begin{array}{l}\frac{\text { Total }}{20.4} \\
(37) \\
0.15\end{array}$ \\
\hline Remaining corporations & $\begin{array}{c}(\%) \\
(\mathrm{n}) \\
\chi 2 \text { stat }\end{array}$ & $\begin{array}{l}23.7 \\
(43) \\
0.72\end{array}$ & $\begin{array}{c}19.8 \\
(100) \\
0.00\end{array}$ & $\begin{array}{c}19.0 \\
(174) \\
0.04\end{array}$ & $\begin{array}{c}19.9 \\
(317) \\
0.75\end{array}$ \\
\hline \multicolumn{6}{|c|}{$\begin{array}{r}\text { Panel C: Average Percent Change for Corporations with Negative Returns (average }=-38.0 \text { percent) } \\
\text { Number of Female Directors }\end{array}$} \\
\hline Ethical corporations & $\begin{array}{c}(\%) \\
(\mathrm{n}) \\
\chi^{2} \text { stat }\end{array}$ & $\begin{array}{l}\frac{\text { None }}{\text { na }} \\
(0) \\
\text { NA }\end{array}$ & $\begin{array}{r}\frac{\text { One }}{-6.6} \\
(2) \\
25.92\end{array}$ & $\begin{array}{c}\text { Multiple } \\
-11.9 \\
(4) \\
17.90\end{array}$ & $\begin{array}{r}\text { Total } \\
-10.1 \\
(6) \\
43.82\end{array}$ \\
\hline Remaining corporations & $\begin{array}{c}(\%) \\
(\mathrm{n}) \\
\chi 2 \text { stat }\end{array}$ & $\begin{array}{r}-50.4 \\
(9) \\
4.07\end{array}$ & $\begin{array}{c}-48.1 \\
(25) \\
2.70\end{array}$ & $\begin{array}{c}-34.4 \\
(55) \\
0.34\end{array}$ & $\begin{array}{r}-39.8 \\
(89) \\
7.11\end{array}$ \\
\hline
\end{tabular}


When considering the effect that women on the board have on the financial returns, it was interesting to find that stock prices varied by the direction of the return. While the corporations on either CRM's or EM's list had significantly greater increases in their stock prices compared to corporations not on these lists, this was not the case when we divided the sample into groups with gains versus losses. When analyzing the gains separately, our results indicated that being on $C R M$ 's list had the opposite of what we anticipated. The corporations not listed by $C R M$ had a slightly higher (3.3 percent) gain; however, the difference was not significant. There was not a difference with respect to the corporations on (not on) EM's list. The data did not support our research hypothesis dealing with corporate reputation and stock prices for corporations with positive returns.

When analyzing the losses separately, our results indicated that being on CRM's or EM's list was significantly associated with a reduction in price declines The corporations listed by $C R M$ had a significantly lower loss in value than the corporations not on this list $(-9.1$ and -45.2 percent respectively). The corporations listed by EM also had a significantly lower loss in value than the corporations not on this list (-10.1 and -39.9 percent respectively). Consequently, there appears to be an economic benefit to being on either of these lists.

When we tested our data for the proportion for female directors, we used the same groupings as we did to test for changes in stock prices (i.e., overall change and increasing-anddecreasing stock prices. The corporations listed by CRM consistently had a lower number of corporations with no female directors or only one female director and a higher than expected number of corporations with multiple female directors. The opposite was true for corporations that were not listed by $C R M$; a higher number of these corporations had no female directors or only one female director and a lower than expected number with multiple female directors. The corporations listed by $E M$ had a lower number of corporations with no female directors or only one female director and a higher than expected number of corporations with multiple female directors. The opposite was true for corporations that were not listed by EM; these corporations consistently had a higher number with no female directors or only one female director and a lower than expected number of corporations with multiple female directors.

The combined findings indicate that corporations on either CRM's or EM's list have a higher than expected number of boards that include multiple female directors. Additionally, the 
corporations on these lists are more likely to have higher overall changes in stock prices and lower decreases in their stock prices. The stock performance figures imply that higher numbers of women on boards may be able to alter the internal elements of an organization, thus decreasing the likelihood of a loss in value to shareholders.

There are four inherent limitations to our study. First, we included only corporations listed in the 2010 Fortune 500. Our second limitation is that we used only CRM's '100 Best Corporate Citizens List' and EM's 2010 'World's Most Ethical Companies' lists. Third, we examined only the effect of having female directors on boards of directors. Fourth, we used only changes in common stock prices. These limitations provide opportunities for future research in this area that include examining: a more diverse corporate sample; using other measures of corporate social responsibility; including minorities as board members; and, using other measures of financial performance.

Future research could take the form of a longitudinal study that determines whether the organizations with a lower female boardroom presence experienced larger stock losses for a longer time period. Future studies might also consider using return on assets and return on equity as internal corporate performance measures to test whether the number of women on a board has an impact on these figures. Finally, future research could also survey investors to determine whether the number of women on the board associates with their valuation of the organization.

Author information: The authors are staff members at the Gabelli School of Business, Roger Williams University, Bristol, RI 02809, United States of America. The corresponding author is Richar A. Bernardi, Professor of Accounting and Ethics: he may be contacted at E-mail: rbernardi@ @rwu.edu or Phone: 1-(401)-254-3672. 


\section{Appendix A}

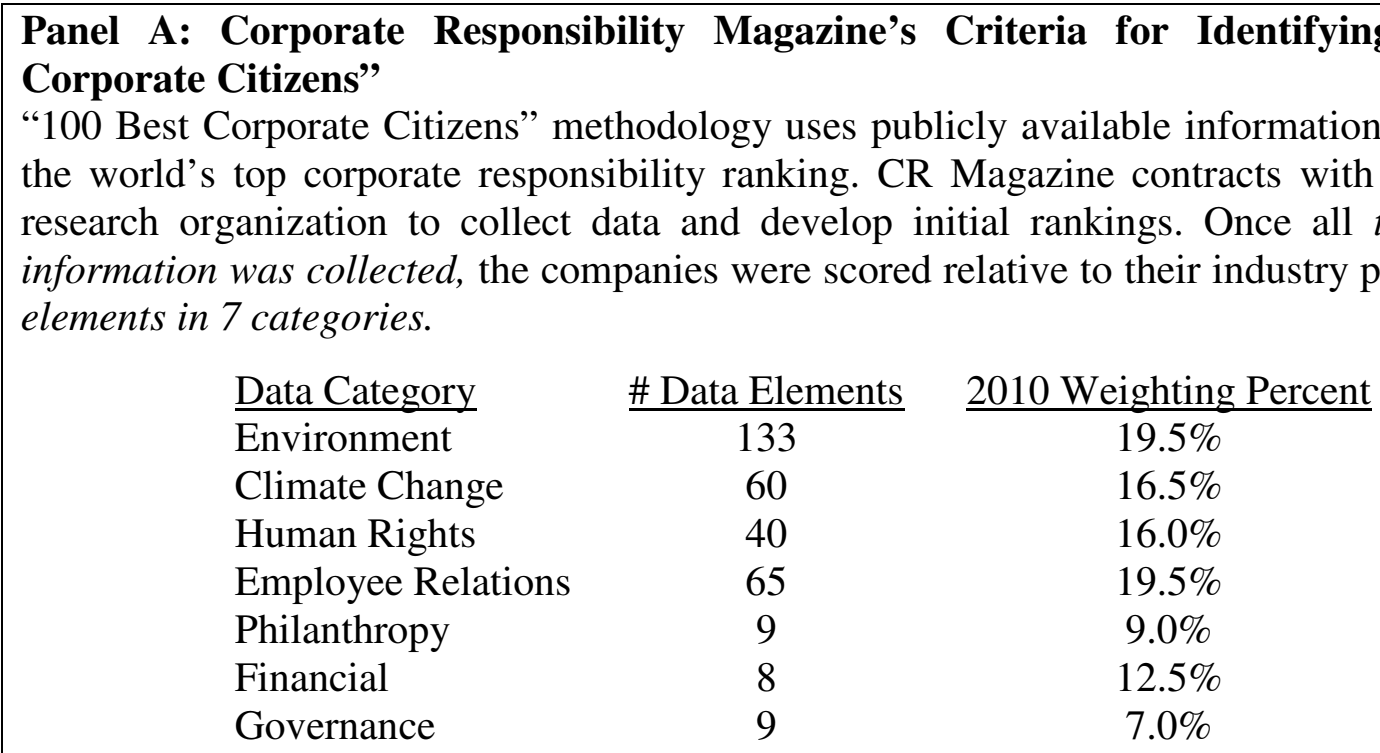

The companies included in the analysis were defined as the 2010 Russell 1000. The rankings are determined from the ordinal list of companies that results from applying the Corporate Citizenship Criteria detailed above.

Panel B: Explanation of Corporate Responsibility Magazine's Process

CR Magazine's researchers and editors employed a detailed process. The separate and sequential analyses conducted were:

STEP $1 \quad$ Selection of and Contracting with a Research Firm

STEP 2 Determination of Evaluation Criteria

STEP 3 Data Collection

STEP 4 Data Sources

STEP 5 Undisclosed Data

STEP 6 Data Validation

STEP 7 Review and Publication

Where:

Steps 1-2 determined that way that analysis would be completed and includes getting input and opinions from NGOs, academics, investment analysts, etc.

Step 3-6 focus on data collection using only publicly available information (company websites, 10-Ks, government datasets, etc.). Undisclosed information negatively influences the company's ranking. Data validation is done by the research team reviewing their work and by providing the opportunity for companies to correct factual inaccuracies.

Step 7 allows companies two opportunities to review the datasets determined by the research team (not their rankings), after this period, the information and rankings are provided to CR. From Corporate Responsibility Magazine (2011)*

*The 2011 methodology details were used as 2010 details were unavailable 


\section{APPENDIX B}

\section{Ethisphere's Criteria for Identifying “The World's Most Ethical Companies"}

World's Most Ethical Companies ${ }^{\mathrm{TM}}$ (WME) methodology analyzes companies that go beyond making statements about doing business 'ethically', to translate those words into action. WME winners demonstrate real and sustained ethical leadership within their industries, putting the Council's credo of "Good, Smart, Business, Profit" into real business practice. The Ethics Quotient (EQ) framework is consists of a series of multiple-choice questions in five core categories. These are used to capture and rate a company's performance in an objective, consistent, and standard manner. The categories and associated weighting are:

1. Ethics and Compliance Program $30 \%$

2. Reputation, Leadership and Innovation $\quad 30 \%$

3. Governance $15 \%$

4. Corporate Citizenship and Responsibility $25 \%$

The EQ score is derived given the relationship to answers provided and formulas based on demographic qualifiers. The top percentile of performers in each of the 35 industries are then independently researched and analyzed to verify ethics performance.

From Ethisphere (2010) 


\section{References}

Adams, R. B., and Ferreira, D., (2009). Women in the boardroom and their impact on governance and performance. Journal of Financial Economics, 94 (2): 291-309.

Adams, S. M., and Flynn, P. M., (2005). Local knowledge advances women's access to corporate boards. Corporate Governance: An International Review, 13 (6): 836-846.

Akaah, I. P., (1989). Differences in research ethics judgments between male and female. Journal of Business Ethics, 8 (5): 375-381.

Arfken, D. E., Bellar, S. L., and Helms, M. M., (2004). The ultimate glass ceiling revisited: The presence of women on corporate boards. Journal of Business Ethics, 50 (2): 177-186.

Arnold, V., Lampe, J. C. and Sutton, S. G., (1997). Understanding the factors underlying ethical organizations: Enabling continuous improvement, Journal of Applied Business Research, 15 (3), $1-18$.

Barber, B., and Odean, T., (2001). Boys will be boys: Gender, overconfidence, and common stock investment. The Quarterly Journal of Economics, 116 (1): 261-292.

Bear, S., Rahman, N., and Post, C., (2010). The impact of board diversity and gender composition on corporate social responsibility and firm reputation. Journal of Business Ethics, 97 (2): 207-221.

Barnett, T., and Schubert, E., (2002). Perceptions of the ethical work climate and convenantal relationships. Journal of Business Ethics, 36 (3): 279-290.

Bernardi, R. A. and Arnold, D. F., (1997). Examination of moral development within public accounting by gender, staff level, and firms. Contemporary Accounting Research, 14 (4): 653668.

Bernardi, R. A., Bean, D. F., and Weippert, K. M., (2002). Signaling gender diversity through annual report pictures: A research note on image management. Accounting, Auditing and Accountability Journal, 15 (4): 609-616.

Bernardi, R. A., Bean, D. F., and Weippert, K. M., (2005). Minority membership on boards of directors: A case for requiring pictures of boards in annual reports, Critical Perspectives on Accounting, 16 (8): 1019-1033.

Bernardi, R. A., Bosco, S. M., and Columb, V., (2009). Does female representation of boards of directors associate with the 'most ethical companies' list? Corporate Reputation Review, 25 (3): 270-280.

Bernardi, R. A., Bosco, S. M., and Reis, K. D., (2004). Corporate leadership in the Fortune 500: women in executive management positions, Journal of Business \& Economics Research, 2 (12): $1-10$. 
Bernardi, R. A., Bosco, S. M., and Vassill, K. M., (2006). Does female representation of boards of directors associate with Fortune's "100 best companies to work for" list? Business and Society, 45 (2): 235-248.

Bernardi, R. A., and Guptill, S. T., (2008). Social desirability response bias, gender and factors influencing organizational commitment: An international study, Journal of Business Ethics, 81 (4): 797-809.

Bernardi, R. A. and Threadgill, V. H., (2010). Women directors and corporate social responsibility, Electronic Journal of Business Ethics and Organizational Studies, 15 (2): 15-21.

Brady, K. T., (2007, November 26). Study finds Fortune 500 companies with more women board members performed better financially. St. Charles County Business Record, p. 1.

Brown, D. A., Brown, D. L., and Anastasopoulos, V., (2002). Women on boards: Not just the right thing but the "bright" thing. The Conference Board of Canada, 1-17.

Burgess, Z., and Tharenou, P., (2002). Women board directors: Characteristics of the few. Journal of Business Ethics, 37 (1): 39-49.

Burke, R. J., (1997). Women on corporate boards of directors: A needed resource. Journal of Business Ethics, 16 (9): 909-915

Campbell, K., and Minguez-Vera, A. M., (2008). Gender diversity in the boardroom and firm financial performance. Journal of Business Ethics, 81 (8): 435-451.

Carter, D. A., D'Sousa, F., Simkins, B. J., and Simpson, W. G., (2008). The diversity of corporate board, committees and financial performance. Working Paper. Available at: http://www.ssn.com/abstract=1106698.

Carter, D. A., Simkins, B. J., and Simpson, W. G., (2003). Corporate governance, board diversity, and firm value. Financial Review, 38 (1): 33-53.

Cohen, R. and Kornfeld, L., (2006). Women leaders and the bottom line. Bloomberg Corporate Law Journal, 1 (1): 1-8.

Corporate Responsibility Magazine, (2011). 2010100 Best Corporate Citizens, Available at: http://www.thecro.com /content/100-best-corporate-citizens

Defond, M., Hann, R. N., and Hu, X., (2005), Does the market value financial expertise on audit committees of boards of directors? Journal of Accounting Research, 43 (2): 153-193.

Donaldson, T., and Preston, L. E., (1995). The stakeholder theory of the corporation: Concepts, evidence, and implications. Academy of Management Review, 20 (1): 65-91.

Ethisphere Magazine: (2011). 2010 World's Most Ethical Companies, Available at: http://www. ethisphere.com/wme2010. 
Farrell, K. A., and Hersch, P. L., (2005) Additions to corporate boards: The effect of gender. Journal of Corporate Finance, 11 (1-2): 85-106.

Fombrun, C., and Shanley, M., (1990). What's in a name? Reputation building and corporate strategy. Academy of Management Journal, 33 (2): 233-235.

Fortune, (2010). Fortune 500, Arnold Bernhard and Co., New York.

Goodpaster, K. E., (1991). Business ethics and stakeholder analysis. Business Ethics Quarterly, 1 (1): 53-73.

GovernanceMetrics International, (2010). Women on boards: A statistical review by country, supersector and sector, pp. 1-13. Available at: http://www.gmiratings.com/(bnnl3555sqbsvh551 v2jfs55)/hp/Women_on_Boards_-_A_Statistical_Review_from_GMI_-_3 _2_09.pdf.

Gul, F. A., Srinidhi, B., and Ng, A. C., (2011). Does board gender diversity improve the informativeness of stock prices? Journal of Accounting and Economics, 51 (3): 314-338.

Harrison, L. E., (1992). Who Prospers? How Cultural Values Shape Economic and Political Success, Basic Books: New Haven.

Huang, H., Y. Yan, J.M. Fornaro, and A. Elshhat. (2011). Market reactions to audit committee director's gender: Evidence from US-Traded Foreign Firms. International Journal of Banking and Finance 8 (1), Article 4.

Huang, J., and D. Kisgen. (2008). Gender and corporate finance. Working paper, Boston College. Available at: http://www.usc.edu/ schools/business/FBE/seminars/papers/F_10-308_KISGEN-Gender. Pdf.

Ittonen, K., Miettinen, J., and Vahamaa, S., (2007), Does female representation in audit committees affect audit fees? Available at: http://www.aaahq.org/audit/midyear/08midyear/ papers/61_Ittonen_DoesFemaleRepresentation.pdf.

Jackson, K., (2004). Building reputational capital: Strategies for integrity and fair play that improve the bottom line, New York: Oxford University Press.

KPMG, (2003). Audit committee roundtable highlights, Available at: http://www.kpmg.com /aci/roundtable_highlights.asp.

Kramer, V. W., Konrad, A. M., Erkut, S., and Hooper, M. J., (2007). Critical mass on corporate boards: Why three or more women enhance governance. Directors Monthly, February, 19-22.

Kravitz, D. A., (2003). More women in the workplace: Is there a payoff in firm performance? The Academy of Management Executive, 17 (3): 148-149.

Larkin, J., (2003). Strategic reputation risk management. New York: Palgrave MacMillan.

Lehman, C., (1992). Accounting's changing role in social conflict, Paul Chapman: London. 
Lundeberg, M. A., Fox, P. W., and Punćcohaŕ, J., (2000). Highly confident but wrong: Gender differences and similarities in confidence judgments. Journal of Educational Psychology, 86 (1): 114-121.

McDaniel, C., Schoeps, N., and Lincourt, G., (2001). Organizational ethics: Perceptions of employees by gender. Journal of Business Ethics, 33 (3): 245-256.

Miles, M. and Covin, J., (2000). Environmental marketing: A source of reputational, competitive, and financial advantage. Journal of Business Ethics, 23 (3): 299-311.

Nguyen, H., and Faff, R., (2006). Impact of board size and board diversity on firm value: Australian evidence, Corporate Ownership and Control 4 (2): 24-32.

Parrett, W. G., (2004). 'Globalization's next frontier: principled codes of conduct bolster the rule of law.' Speech to International Center for Corporate Accountability, United Nations, May 17, Available at: http://www.iasplus.com/resource/0405wparrett.pdf.

Peterson, C. A., and Philpot, J., (2007). Women's roles on U.S. Fortune 500 boards: Director expertise and committee memberships. Journal of Business Ethics, 72 (2): 177-196.

PricewaterhouseCoopers, (2003). Understanding the independent auditor's role in building public trust: A white paper, PricewaterhouseCoopers International. Available at: http://www.uic. edu/classes/actg/actg593/Readings/Sarbanes-Oxley/PWC-Sox-Act-White-Paper.pdf

Reinstein, A. and McMillan, J. J., (2004). The Enron debacle: More than a perfect storm. Critical Perspectives on Accounting, 15 (5/6): 955-970.

Reynolds, S. J., (2003). Perceptions of organizational ethicality: Do inflated perceptions of self lead to inflated perceptions of the organization? Journal of Business Ethics, 42 (3): 253-266.

Schneider, B., (1987). The People Make the Place. Personnel Psychology 40 (Fall): 19-39.

Sims, R., (1994). Ethics and organizational decision-making: A call for renewal. Westport, CT: Quorum Books.

Smalhout, J., (2003). Barron's, January 27 (1): 35.

Sparks, R., (1998). The challenge of ethical investment, In I. Jones and M. Pollitt (Eds.), The role of business ethics in economic performance: 141-170. New York: St. Martin's Press.

Special Report, (1977). Out of the typing pool and onto the board: A list of women directors. Business and Society Review, 22: 27-34.

The Economist, (2000). Business ethics: Doing well by doing good. The Economist, 355 (8167), 65-67.

Thiruvadi, S. and Huang, H. W., (2011). Audit committee gender differences and earnings management. Gender in Management: An International Journal, 26 (7): 483-498. 
Tsoutsoura, M., (2004). Corporate social responsibility and financial performance. Working paper, Haas School of Business, University of California at Berkeley.

Vergin, R., and Qoronfleh, M., (1998). Corporate reputation and the stock market. Business Horizons, 41 (1): 19-26.

Wang, Y., and Clift, B., (2009). Is there a "business case" for board diversity? Pacific Accounting Review, 21 (2): 88-103.

Williams, R. J., (2003). Women on Corporate Boards of Directors and Their Influence on Corporate Philanthropy. Journal of Business Ethics, 42 (1): 1-10. 